\title{
The Modern Legality of Frontinus' Stratagems
}

Today the relevance of ancient military history to modern warfare and strategic theory is a question not often posed ${ }^{1}$. Modern theorists often view war chiefly in terms of military hardware, i. e., machines and technology ${ }^{2}$. Studies of military thought tend to begin with the Renaissance or the French Revolution, as if nothing of importance occurred earlier or, if some significance is conceded, only lip service is due ${ }^{3}$. This attitude in published works surfaced already in the nineteenth century. The philosopher of modern war par excellence, Carl von Clausewitz, rejected use of historical examples from ancient history, as did Sir Edward Bruce Hamley, an English disciple of the Swiss interpreter of Napoleonic warfare Antoine Henri Jomini. For these theorists ancient history could no longer be profitably applied: the sources were too obscure and scanty for proper analysis of events and the means and organization of armies had changed too much ${ }^{4}$. In brief, this attitude supposes that changes in technology eliminate the relevance of ancient military history for understanding the modern phenomenon of war.

Yet another view is also possible. Despite the desires and arguments of pacifists and moralists, war has been a constant in history. Few would dispute that nations of the twentieth century wage war for basically the same reasons as Greeks and Romans. Indeed arguments of continuity between ancient and modern warfare can be presented to counter those stressing change. High technology and nuclear arms have not deterred one polemologist from writting that the concepts and conduct of international relations have changed little since antiquity, and another scholar has argued that technology is the only significant difference between ancient and modern views of warfare ${ }^{5}$. More specific points can also be cited : first, the history of sieges, the oldest form of total war, suggests that neither technological advances nor the democratic revolution influenced the characteristic lack of distinction between combatants and noncombatants; second, inventions such as the tank changed the pace and appearance of modern campaigns without altering the nature of battle; and third, although the means of command vary with technology, the functions of command do not, and improved technology does not necessarily yield a better command structure ${ }^{6}$. According to this school of thought only the face and not the character of war changes with technology; strong threads of continuity are thickly woven within its basic fabric.

For the historian of ancient military affairs the problems of change and continuity in the history of warfare present a dilemma. How can the ancient military historian recapture the essence of Greek and Roman military operations? Is it possible to find a suitable basis of comparison between ancient and modern warfare and, if so, would the degree of continuity thus proven not permit some assertion of the continued relevance of ancient military history to the study of war? The school of change, however, occupies a strong position, since the rejection of ancient military history as the result of technological advances cannot be easily denied. In contrast, the school of continuity often offers plausible but highly subjective interpretations on isolated points. An explicit, detailed, and objective case for continuity has never been presented. The following study seeks, first, to work out a methodology providing a suitable basis of comparison between ancient and modern warfare - one avoiding the hurdle of technological change, while demonstrating the case for continuity - and, second, to offer a modest plea for the continued relevance of the study of ancient military history. The historian of ancient military affairs is, after all, the practitioner of an historical genre once highly venerated and thought of the greatest practical application, but now relegated to the cloisters of academe or diluted into popularization. 
Just as other genres of history, military history has succumbed to the period specialists. Few dare anymore to cast a scholarly glance beyond their narrow niches and to catch even a glimpse of the history of war as a whole, unless of course their purpose is a brief survey volume aimed for undergraduate consumption in a college course. Indeed a noted Byzantinist has recently recognized a crisis in military historiography, in which historians now fail to ask the right questions ${ }^{7}$. Most contemporary scholars of Classical military history do not deviate from this pattern. Most in fact probably consider themselves exclusively ancient historians and feel little or no affinity to the field of military history which they also (perhaps unwittingly) contribute - a symptom of compartmentalization in contemporary historiography. A plea for continuity and thus relevance seems long overdue.

The assault on the school of change must be launched from an analysis of military historiography. When historians look at the history of war as a whole, two categories of change, apart from emphasis on the brilliance (or stupidity) of individual commanders, tend to receive the most notice: first, technology; and second, the organization of the fighting forces, which over the last two decades has come to include analysis of the social composition of armies. Technology, however, often dictates organization, for men must be placed in manageable units to exploit best the weapons at their disposal. Thus, with the exception of those surveying military history as a whole to prove the validity of a specific theory of operations, such as Liddell Hart and his indirect approach ${ }^{8}$, the history of warfare tends to be seen as a matter of generals, technology, and organized masses of men ${ }^{9}$. The actual conduct of operations, stripped of all details peculiar to the historical event under consideration, is generally thought to be governed by basic do's and don't's guaranteeing success if properly observed - the so-called principles of war. These principles are taken as a constant, although their historical validity has never been proved nor has general agreement on their number, identity, and definition ever occurred $^{10}$.

Yet another set of rules, quite different from the principles of war, also comes into play - rules governing the intensity, ferocity, and the degree of trickery permitted in the conflict. These rules, constituting military ethics in its broadest sense as well as the customs and usages of war, might be generally characterized as an unwritten warrior code. Throughout history aspects of the unwritten warrior code have worked their way into international law, and especially since the nineteenth century humanitarian considerations converted into international conventions have attempted to limit war's ferocity ${ }^{11}$. Intensity and trickery, however, remain in a gray area between written rules of conduct and the unwritten warrior code. The degree of violence in war, i. e., its intensity, often functions according to the principles of escalation and reciprocity: raising the level of violence beyond that normally expected will provoke a response in kind or even retaliation at a higher level. Trickery works in much the same way, but the key to its effectiveness lies in exploitation of what is normally expected. Whereas increasing the intensity of violence almost always employs direct and open means, the trickery of stratagem manipulates the secret, the unexpected, and the underhanded. Some degree of trickery is legitimate and to be expected, but other forms of trickery provoke the outraged cries of perfidy and treachery. The border between legitimate ruse and treachery, conditioned by the warrior code dictating the expectations of the parties in a particular period, has never been and, from a practical point of view, probably never can be clearly drawn. Yet trickery, a much more economic means to victory than direct 
escalation of violence, has greater repercussions, since it can destroy any notion of good faith between combatants with the result of both raising the level of intensity and reducing the possibilities of reconciliation between opponents.

An unwritten warrior code and the level of normal expectation it projects reflect the values of the combating parties. Warfare has always been a matter of honor. The supranational brotherhood of arms, best illustrated by medieval chivalry and which continues to affect Western military traditions even today, calls for rules and limitations on violence $^{12}$. Yet chivalrous practice has existed in many societies at various periods, sometimes having a religious basis and often reflecting the exclusiveness of aristocracies to whom the warrior function was primarily limited ${ }^{13}$. The game must have rules and be played fairly. The Western heroic tradition stemming from Homer, which has had no small affect on shaping Western military traditions and thought, places a premium on honor and the use of open, direct means by which manly virtues, above all, courage, can be displayed to the fullest. In the Western view the glory of victory should not be tainted by subterfuge and ruse. Besides, trickery is not only dishonorable, but the recourse of the weak. Thus the unwritten warrior code of the West has taken Achilles as its model, but the ethos of the wily Odysseus, ever devising tricks to secure his goals, has not been forgotten despite efforts to suppress it. A certain tension exists between the two in Western military history, for the unconventional and unorthodox commander has always appeared, who remains unconvinced that the brawn of the strong rather than wit and intelligence is the best military means to an end.

Of course a warrior code, like international law, only possesses validity within a group sharing common values and composing a part of the system. Rules or restraints need not apply when Greeks and Romans oppose barbarians, Christians fight infidels, or civilized nations confront heathen savages. In theory the charter of the United Nations has eliminated all such distinctions between insiders and outsiders ${ }^{14}$.

This very schematic sketch of military historiography and the kinds of rules operating in the conduct of war is intended to add some elements of continuity in the history of war to those already mentioned. Certainly other constants could be noted, for any general must confront problems of terrain, weather, movement, and supplies. But these physical problems find their solutions in ever changing technology, whereas an unwritten warrior code, although no doubt historically conditioned by its time, reflects the traits of human behavior and attitudes fostered by a tradition passed on from generation to generation.

Factors of non-change and continuity are of the utmost importance in comparative history, especially if, as here, a comparison is to be drawn between such chronological poles as the warfare in Classical antiquity and today. We have cast the problem in terms of historiography and rules: the former, because it determines what the history is through interpretation of the raw data and the methodology used to derive that interpretation; and the latter, because rules, despite the influence of the Zeitgeist in their establishment and definition, afford a much more objective criterion for judgement than other factors involving countless variables and value judgements ${ }^{15}$. Furthermore, rules of war and international law, which often represents the sanctioning of customs and unwritten rules already long in use, are not necessarily a function of technology. Our problem is not the evolution of laws of war, a question too complicated and far ranging for discussion here. We must be content to show objectively that a continuity of rules exists - the proper first step before any meaningful assessment of changes in rules can be attempted.

Comparisons of ancient and modern warfare are, of course, not new. From the sixteenth to the nineteenth century the study of ancient warfare had a practical purpose not only for general military education to instruct in the commander's art from the bat- 
tles of Alexander, Hannibal, and Caesar, but also for practical adaptation of ancient formations on the battlefield. Clausewitz, as noted earlier, reacted to these trends ${ }^{16}$. Nevertheless, even when French and German armies marched off to confront each other in August 1914, both did so under classically inspired doctrines.

In the mid-nineteenth century the French officer Ardant du Picq derived from a study of ancient battles that the concept of shock in combat was a myth. Success in battle was a matter of morale, since the collision of one tactical mass with another rarely occurred: either the attackers lost heart before making contact or the defenders fled. Ancient battles showed that the greatest casualties befell the side in flight, not in battle per se. Du Picq's writings, posthumously published as Études sur le combat in 1902, were distorted and manipulated by Ferdinand Foch and Colonel de Grandmaison into the French doctrine of the offensive, in which they emphasized the will to victory, i. e., never admitting defeat no matter how many machine guns in entrenched positions the French attackers faced. Similarly, Alfred von Schlieffen's fascination with Hannibal's victory at Cannae provided the inspiration for the famous Schlieffen Plan, formulated during von Schlieffen's tenure as Chief of the German General Staff $1891-1906{ }^{17}$. The problem posed in this paper, however, is not the influence of the Classical tradition on modern military thought, but how to find a suitable basis of comparison between ancient and modern warfare.

Since the nineteenth century when the conduct of ancient campaigns and battles ceased to be, for the most part, a textbook for generals and became primarily a subject of research for academics, attempts to recapture the essence of ancient warfare have chiefly relied on two methodologies: Sachkritik (objective analysis or inherent military probability), developed by Hans Delbrück, and topographical studies, promoted by Johannes Kromayer and Georg Veith ${ }^{18}$. The two are not mutually exclusive. Sachkritik involves reasoned criticism of ancient accounts based upon what is known to be physically possible for men and animals, how masses of men in modern armies are organized and move, knowledge of basic tactical and strategic principles, experiments to recreate ancient formations, and consideration of an event's geographical, political, economic, and social contexts. Sacbkritik further includes Wortkritik, rigorous philological source criticism ${ }^{19}$. In contrast, the topographers often tend to take a more credulous approach to the ancient sources and believe that ancient battles can only be accurately reconstructed by a study of the terrain.

Controversy between the two schools sparked a hot and often ugly debate in the early years of this century. As the first historian to apply the scientific methods of Leopold von Ranke to military history and as an exploiter of the groundbreaking demographic work of Julius Beloch, Delbrück aroused the ire of such notables as Ulrich von Wilamowitz, Eduard Meyer, Adolf Bauer, and especially Kromayer. The controversy cannot be characterized as the conflict of Sachkritik and topographical studies, since Delbrück fully appreciated the contributions of topographical studies and included them within his concept of Sachkritik ${ }^{20}$. Rather, Delbrück's hypercritical approach to the ancient sources and excessive reliance on modern analogies, not to mention clashes of personalities and the impertinence of an »outsider « arguing against views of established Classical historians, fueled the fire of debate ${ }^{21}$.

No doubt Delbrück tried to take his methodology too far. His interpretations of Marathon, which initially sparked the controversy, as well as of other ancient battles no longer attract much scholarly attention. The topographers, however, by no means offer a panacea. Topography changes in the course of 2000 years; the precise location of battlefields can remain uncertain; or even when the general site is known, whether the battle occurred on one side of the river or another is not always clear. Topographical studies have not solved all the problems surrounding such battles as Marathon, Can- 
nae, Zama, and Pharsalus, to name only a few. A critical approach to ancient military history is not possible without Sachkritik, and a recently much applauded study of Alexander the Great's logistics, combining Sachkritik and topographical studies, is (perhaps unbeknownst to its author) a work in the spirit of Delbrück ${ }^{22}$.

The methodologies of Sachkritik and topographical studies have their place in attempts to reconstruct ancient battles, but are less valuable when trying to grasp some sense of how ancient and modern warfare really compare. Sachkritik may employ parallels between details of ancient and modern campaigns from narrative sources, but this is piecemeal work offering only a sketchy impression and involving arbitrariness in selection. The concept of rules, we believe, offers the most objective criterion. Analysis by a set of rules also permits to avoid the greatest and most obvious hurdle in comparison of ancient and modern warfare - the difference in technology. Our comparison will stress what is done and not how. But whose rules should be used and rules about what?

Examination of the factors (outlined above), subject to rules and found in both ancient and modern warfare, soon reveals that the concept of stratagem has received the least scholarly attention and is also the most problematic, as some scholars have only recently noticed ${ }^{23}$. Employment of trickery and deception in warfare not only involves tactical and strategic practice, but also raises questions of military ethics and the laws of war. What are the rules of the game and how far can they be bent before perfidy and treachery occur? The legal aspects of stratagem in the history of the laws of war and of international law still beg for detailed attention ${ }^{24}$. This gap in scholarship can be at least partially closed by reducing our comparison of ancient and modern warfare to analysis of the practice of stratagem according to the laws of war. Before turning to our specific methodology, a few words on stratagem in antiquity are in order, as well as how such a topic, which would seemingly involve scattered evidence arbitrarily selected, can be manageably handled.

The concept of stratagem is as old as war itself. Warfare among primitive peoples draws its chief characteristics from stratagem in its forms as ambush, surprise attack, feigned retreat, treachery, and even poisoned weapons ${ }^{25}$. From the beginning of the Western tradition with Homer, stratagem is present in the wiles of Odysseus and the Trojan Horse, and the first Greek historians Herodotus and Thucydides initiate military trickery in Western historiography. In the fourth century B. C. military theory branches off from history into its own genre under the influence both of the sophists and their development of the technical handbook and of the trends away from the traditional warrior code of archaic Greece surfacing in the Peloponnesian War. Xenophon and Aeneas Tacticus, the earliest extant Western theorists, emphasize stratagem more than any other element in warfare ${ }^{26}$. The subsequent split of ancient military literature into writings on tactics and generalship, following the themes of Xenophon, and on siegecraft, ultimately modeled on Aeneas Tacticus, in no way diminished stratagem's prominence.

At some point during the Hellenistic period collections of examples of stratagems began to be compiled and became popular. The origins of this genre are obscure. Schools for rhetorical training collected examples of vices and virtues for consultation in composition of speeches. Collections of examples of deeds by famous men, a form of historical epitome, also flourished. In addition, the Peripatetic passion for collecting examples of all kinds of phenomena offered some impetus. An extant example of these collections of anecdotes, the Facta ac dicta memorabilia by Valerius Maximus, demonstrates that stratagems could be included, but collections exclusively of stratagems for purposes of military instruction probably appeared at an early date. Aeneas Tacticus in the fourth century B. C. already shows an inclination for assembling lists of examples and Polybius in the second century B. C. may have consulted a stratagem collection ${ }^{27}$. 
Only two complete collections of stratagems, one in Latin and one in Greek, the Strategemata by Sextus Julius Frontinus (d. 103) and the Strategika by Polyaenus (fl. 160) respectively, have been preserved from what was probably a rather extensive body of literature. The two contrast sharply in organization, orientation, and the backgrounds of their respective authors, although they have a common purpose in providing instruction for generals through examples from history.

Frontinus led a brilliant public and military career in the Flavian era and the early years of the Emperor Trajan. He held the consulship three times $(73,98,100)$; governed Britain 74-78, where he subjugated the Silures in southern Wales; probably also commanded in Lower Germany 82-84, during which time he possibly served in the Emperor Domitian's war against the German Chatti; and capped his career with the prestigious proconsulship of Asia in 86/7. At Rome his circle of friends included Pliny the Younger and Sosius Senecio (cos. 99, 107), his son-in-law and the patron of Plutarch. He also provided patronage for the poet Martial as well as the Greek military writer Aelianus Tacticus ${ }^{28}$. His own literary endeavors display a technical bent. His De aquis describing the water and sewer system of Rome reflects his experience as commissioner of water works (curator aquarum) in 97, while his De officio legati belongs to a genre of juristic literature detailing the functions of specific public offices ${ }^{29}$. A treatise of unknown title on surveying, the first work on this subject in Latin, appeared under Domitian and a book on agriculture is lost. Finally, his military works consist of a book on Homer as a tactician and a lost comprehensive treatise on military theory, exploited as a source by Vegetius in the late fourth century for his De re militari. The Strategemata, probably written in the period $84-88$, formed an appendix to the lost comprehensive treatise (Front., Strat. 1 praef. 1).

The Strategemata is clearly designed for practical use and ready reference. Frontinus provides tables of contents to each of the four books organized by stratagems to be used before, during, and after battle as well as ruses for siegecraft. More significantly, however, Frontinus draws a firm distinction between strategika and strategemata. Greek strategika as a neuter plural adjective used substantively denotes the properties of a general or generalship and in book titles military affairs in general. The word strategema first occurs in Xenophon, apparently meaning "principles or examples of generalship«, and its specific definition as »military trick " is only first secure in Philo of Byzantium at the end of the third century B. C. and in Polybius in the second century B. C. ${ }^{30}$. In Greek the two words were initially synonyms. Even after strategema acquired its more specialized meaning as trick, it could still appear in some cases as the equivalent of strategika. Nevertheless, Frontinus sharply defines strategemata as a subset of strategika: strategika denote the deeds of generals done with foresight, expediency, steadfastness, restraint, and justice, but strategemata refer only to offensive or defensive acts characterized by craft and cleverness, in short, the clever deeds of generals (sollertia ducum facta) ${ }^{31}$. Moreover, this distinction is scrupulously observed: books $1-3$ and 4.7 contain strategemata and 4.1-6 strategika.

In contrast to Frontinus very little is known about Polyaenus ${ }^{32}$. He apparently had followed a career in law and was too old for military service, when c. 161 Rome and Parthia began the war which occasioned his Strategika. The work is divided into eight books, each with its own dedicatory preface to the Emperors Marcus Aurelius and Lucius Verus, perhaps indicating that each book was published separately. Since no reference to Verus' departure for the war in spring 162 occurs until the preface to the sixth book and no allusion to the end of the war appears, the work must have been completed before 165. Polyaenus never mentions his sources and there is no proof that he used Frontinus, although the possibility that both drew on common sources cannot be denied. No tables of contents to aid quick reference are found in the Greek work, which 
is organized by the stratagems of individual generals and nations rather than by practical topics. Furthermore, as a Greek writing in his native tongue, Polyaenus feels no compulsion to define what he means by strategemata. The manuscript tradition is clear that the title of the work is Strategika rather than Strategemata, although titles in manuscripts can be the attribution of scribes or copyists and not of the author. In any event, Polyaenus makes no distinction between anecdotes of strategika and strategemata.

This brief comparison of the only two extant stratagem collections yields that Frontinus' Strategemata rather than Polyaenus' Strategika provides the best source of ancient evidence on stratagems for our study. His collection includes anecdotes of events ranging in date from the sixth century B. C. to the first century A. D. and, more significantly, he not only rigorously defines stratagem but also scrupulously follows his definition in the organization of his work - an aspect totally lacking in Polyaenus. Furthermore, no analysis of the legality of Frontinus' stratagems by either ancient or modern standards of the laws of war has ever been attempted (although the same could be said for Polyaenus). Classicists have concerned themselves only with the authenticity of the fourth book, the historicity of specific stratagems, and Quellenforschung ${ }^{33}$. In contrast, modern writers on military deception (to the extent that they acknowledge at all that the concept of stratagem is not exclusively an idea of the twentieth century) pay only lip service to Frontinus ${ }^{34}$.

Indeed a modern writer on laws of war offers the perfect testable hypothesis for our comparison of ancient and modern warfare. According to Fleck legal considerations are marginal in Frontinus and Polyaenus and the ethics of ancient stratagems are questionable ${ }^{35}$. If Fleck's statement is generally true, then one would expect to find Frontinus' Strategemata full of acts violating contemporary laws of war. Thus our task becomes analysis of Frontinus' stratagems by modern standards of the laws of war. This exercise, although not completely devoid of subjective elements (as will be outlined below) presents the opportunity for a much more objective insight into how ancient and modern warfare really compare than any parallels between details of ancient and modern campaigns drawn from narrative sources could offer. Moreover, differences in technology cannot affect the results: the problem is of rules, not of means. It also seems fair to add that Frontinus' Strategemata provides an unbiased sampling of the available evidence. How in fact could he have weighted the evidence for or against twentiethcentury laws of war?

Before turning to Frontinus' anecdotes, the methodology of this study should be specified. First, we proceed from the basic premise that any human act may be judged legal or illegal, ethical or unethical. Not all of the 583 anecdotes in the Strategemata raise legal or ethical issues, unless of course human cleverness and ingenuity be judged somehow unethical. In Section III we have selected for discussion only those anecdotes which arouse suspicion that they might involve violations of the modern laws of war. All other stratagems in Frontinus appear in our opinion to be legitimate ruses.

Second, Frontinus' own evaluation of the legality of individual stratagems is not the point of this study. We seek a comparison of ancient and modern warfare to determine explicitly and as objectively as possible the extent of continuity in rules. Ancient practice must be judged by modern standards to achieve this goal. It cannot be argued that Frontinus viewed all the stratagems in his collection as legitimate, because he did not, and we shall discuss briefly in Section IV the kinds of stratagems of which Frontinus disapproved.

Third, the modern criterion by which we shall judge Frontinus' stratagems will be the United States' standard army manual on the laws of war, The Law of Land Warfare ${ }^{36}$. This text will be supplemented for clarifications, as needed, with other works and com- 
mentaries on international law. Use of the American manual reflects accessibility to the writer rather than ethnocentrism, and analysis of Frontinus by a British, French, German, or other national manual would probably not yield significantly different results ${ }^{37}$.

Fourth, the modus operandi will be as follows. A brief summary of current law outlining specific areas of infractions will be presented. Next anecdotes from Frontinus suspected of illustrating violations of current law will be discussed, grouped by categories of violations. Since Frontinus' anecdotes are composed to illustrate succinctly a particular stratagem and all pertinent details for judging a violation of the laws of war do not always appear, brief commentaries to justify classification as legitimate or illegitimate conduct will be offered. Furthermore, Frontinus' distinction of strategika from strategemata will be preserved. Hence the sample includes 484 stratagems (Strat. 1-3, 4.7) of the 583 anecdotes in the Strategemata ${ }^{38}$. Finally, the historicity of individual anecdotes is not at issue in this paper and the question will not be raised. Accordingly, parallel references from other sources to the stratagems (available elsewhere, e.g., the edition of Frontinus in the Loeb Classical Library) will not clutter the footnotes.

The modern law on stratagem is fairly simple: all stratagems are permitted, provided that they do not involve perfidy, treachery, or a breach of good faith, and do not violate any generally accepted rules. Spies and bribery of enemy soldiers or civilians to induce defection, rebellion, desertion, or surrender are legitimate, as are all means to mystify, mislead, and deceive the enemy. Treachery and perfidy occur, however, when a moral obligation to speak the truth is violated, such as breaches of a truce and terms of surrender, or feigning surrender then injuring one's captors, or accepting surrender and then harming the prisoners. Lying to the enemy under other circumstances is acceptable ${ }^{39}$.

The concept of treachery also extends to certain military conventions. Improper use of a flag of truce, the enemy's national flag, uniforms, or insignia, and the emblem of the Red Cross is prohibited. A flag of truce may not be used for intelligence gathering, to cover a retreat, or to effect surprise. »Improper use " of national flags, uniforms, and insignia generally means their employment during combat, thus permitting these in stratagems before or after combat ${ }^{40}$. A further prohibition connected with stratagem is the ban on treacherous killing and wounding, which applies to assassination or proscription, and conceptually also extends to the use of poison or poisoned weapons ${ }^{41}$.

This brief overview of the "rules of the game« is only intended to give an impression. The actual complexity of some of these rules in practice will become clearer in the discussion of violations found in Frontinus. To supplement and to clarify some of the rules, the following list includes those rusé acts specifically designated war crimes: use of poisoned or otherwise forbidden arms, treacherous request for quarter, maltreatment of dead bodies, hostilities against undefended localities or those of no military significance, abuse of or hostilities against a flag of truce, misuse of the Red Cross emblem, use of civilian clothing by troops during combat, improper use of privileged buildings for military purposes, poisoning wells or streams, pillage or purposeless destruction, and violation of surrender terms ${ }^{42}$. 
The following anecdotes from Frontinus' Strategemata arouse suspicion that they involve violations of modern laws of war, although some of the apparent breaches of law occur in the anecdotes without being integral parts of the stratagem. Thus in some cases the violations have nothing to do with whether the stratagem itself is illegal.

Violations of a Truce

1.1.7: When Mithridates was blockaded by Pompey and planned to retreat the following day, he concealed his intention by foraging raids and by arranging conferences for a future date with many of his opponents. Then he retreated that night leaving fires blazing throughout his camp. $66 \mathrm{~B}$. C.

1.4.6: Philip V of Macedon, under way to invade Greece, heard that the pass of Thermopylae had been occupied. When the Aetolians sent envoys to discuss peace terms, Philip retained them, rushed to Thermopylae by forced marches, and got through the pass. The guards still awaiting their envoys' return were surprised. $210 \mathrm{~B}$. C.

1.4.13a: A fleet of Byzantine, Rhodian, and Chian ships blocked Philip II of Macedon's passage of the Chersonese. So Philip opened peace negotiations and returned their ships, which he had captured earlier. After Philip had intentionally dragged out the negotiations and the enemy was off guard, he suddenly sailed through the straits.

339 B. C.

1.5.17: During the Social War Sulla was trapped in a defile by the enemy and tried to negotiate terms of peace without success. When he noticed the enemy's negligence as a result of the truce, he marched his army from the defile by night leaving behind only a trumpeter to sound the regular watches and to rejoin the army later. $90 \mathrm{~B}$. C.

1.5.18: Archelaus, the general of Mithridates, had cornered Sulla and his forces of inferior number on rough terrain in Cappadocia. Sulla proposed peace and then exploited the truce which had relaxed the enemy's guard as a means of escape. $92 \mathrm{~B}$. C.

1.5.19: When Claudius Nero caught Hasdrubal, Hannibal's brother, in a defile, negotiations began which Hasdrubal purposefully extended over several days, while secretly sending out detachments of his army by paths unguarded by the Romans. Hasdrubal later escaped in the same way. 211 B. C.

2.13.8: After the Romans defeated Philip V in Epirus, Philip secured a truce for burial of the dead to prevent a Roman pursuit of his army. The relaxed vigilance of the Romans enabled Philip to get away. 198 B. C.

3.2.6: During the Athenian siege of Agrigentum Alcibiades, the Athenian general, requested and was granted permission to address the citizens of the city. While he spoke to the Agrigentines in their theater, the Athenians captured the city. $415 \mathrm{~B}$. C.

1.5.17-19 and 2.13.8 clearly show employment of a truce to cover or to facilitate a retreat, although in 1.5.17 Frontinus does not make it certain the truce is still in effect. A truce must be assumed in 3.2.6, since during a siege Alcibiades would not otherwise have been able to address an assembly of the besieged town. 1.1 .7 indicates a reprehensible use of a truce to deceive the enemy and to facilitate a retreat, but no illegality can be claimed, since the truce (arranged for a future date) is not in effect when the retreat occurs.

1.4.6 and $13 \mathrm{a}$ are very problematic, because in both cases advantage is taken of the enemy during negotiations, an activity which does nor necessarily denote the existence of a truce or prohibit conducting hostilities, and Frontinus does not explicitly refer to truces. The slackness of the guards at Thermopylae in 1.4.6 does not prove the existence of a truce. They could have been simply negligent. Nor can it be argued that Phi- 
lip's detention of envoys in the same anecdote constitutes a violation. This is permissible conduct when the departure of parlementaires could reveal information about troop movements - the situation in this stratagem ${ }^{43}$. Thus all these stratagems are illegal except 1.1.7, 4.6 and $13 a$.

\section{Violations of Agreements}

3.4.3: Dionysius I of Syracuse wanted to attack Rhegium, although it was well stocked with food. So he feigned a desire for peace and acquired provisions from this city for his army, which consumed their stores. Subsequently he attacked and captured the city deprived of its provisions. 391 B. C.

3.4.4: Dionysius repeated the same stratagem against Himera. 387 B. C.

3.4.6: When Phalaris of Agrigentum failed to capture by siege several well fortified Sicilian towns, he made a treaty with them, deposited his own remaining supplies of grain in their storehouses, but made provision that the buildings had leaky roofs. The Sicilians consumed their own supplies, expecting to have Phalaris' grain for emergencies. Phalaris, however, attacked and hunger forced their surrender. At some point 570554 B. C.

3.17.3: Livius, the Roman commander holding the citadel of Tarentum against the Carthaginians, requested the right to withdraw in safety. The enemy relaxed their guard and Livius destroyed them with a surprise sally. At some point 212-209 B. C. 4.7.17: The Athenian Paches stated that the enemy would be spared if they laid down their steel (ferrum). When they deposited their swords in compliance with the terms, Paches ordered them executed since they still had steel broaches on their cloaks. c. 427 B. C.

4.7.18: Hasdrubal invaded Numidia, but countered initial resistance with the pretext that he came to hunt elephants and would pay the Numidians for this privilege. The Numidians accepted the story and were subjugated. Date unknown.

3.17.3 and 4.7.17 are unquestionably breaches of agreements. 4.7.17 has the distinction both of illustrating a sophistic interpretation of surrender terms, i. e., an overly literal interpretation contrary to an agreement's spirit or generally accepted meaning, and of relating the execution of prisoners after their surrender, a blatant crime by modern standards ${ }^{44} \cdot 3.4 .3-4$ and 6 , however, do not relate violations of agreements, but rather pacts made in bad faith to reduce the opponent to an inferior position. Frontinus makes no references in the anecdotes to pledges against future aggression between the parties. Nevertheless, most jurists would probably label the pacts treacherous. 4.7.18 cannot be judged a violation. Hasdrubal obviously lied to the Numidians, but he was under no obligation to speak the truth and the Numidians paid the price of their gullibility. All anecdotes in this section except 4.7.18 involve illegalities.

\section{Misuse of the Enemy's Uniform, Insignia, and Flag}

2.5.10: In a war against the Illyrians Alexander of Epirus lured his foes into an ambush by dressing some of his men in Illyrian costumes and having them ravage some Epirote territory. The real Illyrians followed suit with their supposed countrymen and were led into the trap. Date unknown.

2.5.15: The Chians during a war with the Erythraeans killed an Erythraean spy on a high peak and dressed a Chian in his clothes, who signaled to the Erythraeans and seduced them into an ambush. Date unknown.

2.9.9: Peisistratus the Athenian surprised a Megarian fleet which had come to Eleusis by night to kidnap Athenian women during a sacrifice. He then manned the Megarian 
where the Megarians, deceived by appearances, were defeated a second time. c. 600 B. C.

2.9.10: Cimon, the Athenian general, deceived the Persians at the battle of the Eurymedon by approaching their camp in Persian ships and with his men dressed in Persian equipment, which had been taken in another battle with the Persians on the same day. 466 B. C.

3.2.4: When the Arcadians were besieging a fortress of the Messenians, they made weapons resembling those of their opponents. Later they learned that the besieged expected reenforcements, so the Arcadians dressed their men to resemble the attire of the relief force, gained admission to the fortress, and thus captured it by force. Date unknown.

3.2.11: Timarchus, an Aetolian, killed the Ptolemic general Charmades and dressed himself in the dead man's cloak and helmet. In this fashion he was admitted to the harbor of the Sanii and got possession of it. c. 280 B. C.

3.14.1: The Spanish city of Ategua controlled by Pompey's partisans was besieged by the Caesarians. A Moor wanted to lead reenforcements into the city through the Caesarian lines. By pretending to be a Caesarian officer he acquired the password from one outpost and used it to get through the others. $45 \mathrm{~B}$. C.

4.7.12: Marcus Portius Cato, after capturing some Carthaginian ships, distributed the enemy's weapons and insignia among his own men. Thus he was able to deceive and sink other enemy ships. Date unknown.

4.7.23: Iphicrates, the Athenian general, wishing to test the loyalty of a certain town, equipped his own fleet in the fashion of the enemy and sailed there. When the fleet was greeted with enthusiasm, the town's treachery was discovered and Iphicrates sacked the place. At some point 390-389 B. C.

Classification of ancient stratagems under this category would initially seem rather difficult, since uniforms and national flags are usually seen as developments of the early modern period, and use of an enemy's weapons and ships does not constitute a violation of the laws of war, provided of course that the ships do not fly the enemy's flag in combat ${ }^{45}$. A closer examination of Frontinus' language, however, reveals that national costumes could serve the same function as the modern uniform, especially for deception, although with the exception of 3.2.11 specific details of the costumes (whether helmets, belts, tunics, etc.) are lacking. Use of insignia seems consistent with modern usage $^{46}$. Similarly, the naval stratagems $(2.9 .9 ; 4.7 .12,23)$ are not really so problematic as they would appear, since ancient warships did fly flags indicating the state or at least the fleet to which they belonged ${ }^{47}$. We must assume, however, that use of the enemy's ships in these stratagems includes use of the enemy's flag, for which 4.7.23 (classem suam hostili babitu instruxit) offers support.

Although some argue that any use of enemy flags, uniforms, and insignia is illegal, the official view recognizes illegality only as "misuse", understood as "in combat " ${ }^{48}$. Thus only 2.9.9-10 and 4.7.12 are clearly illegal, and 3.14.1 is legitimate because combat is not involved. Similarly, 3.2.11, one man's disguise to effect betrayal, is probably legitimate, since no reference to combat occurs. The remaining anecdotes, however, are very problematic. 2.5.10 and 3.2.4 may be counted illegal because it is implied that those in enemy uniforms participate in combat, whereas 2.5 .15 is legitimate, since the man in disguise only misleads the enemy by signals and does not himself fight. Finally, 4.7.23 appears legitimate, since the disguise of the enemy's flag and/or dress is used not against the enemy but against a third party, a treacherous ally, and not for the purpose of gaining advantage in combat. 
2.1.6: Iphicrates had encamped for several days near the Spartans and each side habitually at a certain time sent out parties for wood and forage. One day Iphicrates dispatched for this purpose slaves and lixae (traders and merchants) dressed as soldiers. When the Spartans following their habit dispersed their forces, Iphicrates captured their camp and killed or took the others prisoner. At some point 393-392 B. C.

2.4.6: At the battle of Aquae Sextiae Marius planned to send a detachment of regular cavalry and infantry to create the illusion of a large force approaching in the enemy rear. To increase the size of this detachment, he ordered agasones (grooms) and lixae to be armed and pack-animals to be equipped as cavalry horses. The detachment was to make its appearance as soon as they heard the sounds of battle. $102 \mathrm{~B}$. C.

2.4.20: When Atheas, a Scythian king, was outnumbered in a struggle with the Triballi, he commanded women, children, and all noncombatants in the population to drive up herds of asses and cattle in the enemy rear and a group holding spears aloft to procede them. In addition, he circulated a rumor that he expected reenforcements. The Triballi withdrew. Date unknown.

3.2.3: Hannibal seized many Italian towns by sending ahead some of his own men dressed as Romans and speaking Latin. In the period 217-203 B. C.

3.2.7: Since the women of an Arcadian town customarily strolled in large numbers outside the walls on a certain holiday, Epaminondas disguised some of his soldiers as women, who mingled in the crowd, gained admittence to the city at dusk, and opened the gates to Epaminondas' forces. 379 B. C.

3.2.8: Aristippus the Spartan, while the population of Tegea celebrated a sacrifice outside their walls, sent to the city a mule-train loaded with grain and driven by soldiers disguised as traders, who seized the gates for the Spartans. Date unknown.

3.2.9: When Antiochus besieged Cappadocian Suenda, he captured and killed a party dispatched to procure grain for the city. His own soldiers assumed the dress of the Cappadocian calones (soldiers' servants), returned to Suenda with the grain, and fooled the city's guard. Date unknown.

3.2.10: After the Thebans had failed to capture the harbor of Sicyon by force, they dispatched a merchant vessel filled with soldiers to the harbor. A few of them disguised as traders and unarmed disembarked. According to the plan they started a fight with some other Thebans at a spot remote from the sea. When the enemy's attention was diverted to this altercation, the Thebans captured the harbor and the city without opposition. 369 B. C.

3.3.6: When Hannibal was trying to take Tarentum, he persuaded Cononesus to turn traitor. Cononesus was to go out hunting at night, an activity which was supposedly prevented by day, and Hannibal would supply him with boars. After Cononesus' successful repetition of this act, Hannibal disguised some of his soldiers as hunters, who were admitted into the city as Cononesus' attendants, killed the guards, and opened the gates. 212 B. C.

4.7.33: Sempronius Gracchus was routed in a battle with the Voccaei, when he attacked their ring of carts apparently occupied by their women, but in reality their best warriors in women's dress. At some point 179-178 B. C.

The stratagems under this heading fall into three categories: first, use of one's civilians to pose as one's own soldiers $(2.1 .6,4.6,20)$; second, disguising one's own soldiers as one's civilians (4.7.33); third, dressing one's own soldiers as the enemy's civilians $(3.2 .3,7-10,3.6)$. Legal analysis of these anecdotes must be based on two principles: do individuals in disguise participate in combat and do they merit consideration as a le- 
gally defined enemy (iustus hostis) who can claim status as a prisoner of war, if captured, rather than treatment as a spy, saboteur, or outlaw? Only 2.4.6 and 4.7.33 involve actual combat and only the latter is a clear violation, since the Voccaei dressed as women both provoke a Roman attack and fight in their disguises ${ }^{49}$. For 2.4.6 the legal question involves not participation in combat since the grooms (agasones) and traders (lixae) are not disguised, but whether these groups are military or civilian and have the right to enter battle, i. e., are legally defined enemies.

The legal definition of an enemy has been since the French Revolution and remains today a burning legal problem, as the trend toward guerilla warfare and terrorism has steadily increased ${ }^{50}$. Current law requires that members of the armed forces of a party to a conflict meet four criteria: be commanded by someone responsible for his subordinates, have a fixed distinctive sign recognizable at a distance, carry arms openly, and conduct operations according to the laws and customs of war ${ }^{51}$. Yet the concern is ancient as well as modern: Cato the Elder in the second century B. C. warned his son, who had been discharged from his legion, that he could not legally serve in the war against Perseus and should not enter battle before he had taken the military oath a second time ${ }^{52}$. In other words, without the bond of the oath he ceased to be in the enemy's eyes a soldier, a legally defined enemy.

Thus are the traders (lixae) and grooms (agasones) of 2.4.6, to which should be added the slaves and traders of 2.1.6 legally defined enemies? Furthermore, let us also consider the soldiers' servants (calones) of 3.2.9, although this case is slightly different: if the calones are regular combatants, then the disguise of one's soldiers as the enemy's calones would either violate the rule of misuse of the enemy's uniform if they entered battle or qualify them as spies or outlaws if they were captured.

The agasones, lixae, and calones all form part of the Roman army's campfollowers. The agasones and calones are thought to be slaves, while the lixae are free ${ }^{53}$. The distinction of slave and free, not recognized by modern international law, can have no bearing on the question. A modern provision states that those accompanying the armed forces without belonging to them, such as supply contractors and members of services responsible for the welfare of the armed forces, merit prisoner of war status. This cannot apply to the lixae, since in one case (2.1.6) they participate in hostile operations posing as soldiers and in another (2.4.6) they appear in combat, situations which this provision was not intended to cover ${ }^{54}$.

The problem can be reduced to the question whether the agasones, lixae, and calones satisfy the modern criteria of an enemy/soldier. We have the most evidence about the calones. According to Vegetius (3.6) the calones were brigaded into units of 200 packhorses and pueri (probably identical with the agasones) under their own officers and possessed their own banners (vexilla) for the various units composing the baggagetrain (impedimenta). Vegetius also notes their Late Roman designation as galiarii indicating use of a helmet ${ }^{55}$. Although Roman gravestones from the middle Danubian provinces always portray soldiers' servants bareheaded and wearing nondescript tunics and interpretation of the figures as calones rather than agasones is moot, helmeted calones are known from gravestones elsewhere ${ }^{56}$. Furthermore, we know calones were armed with cudgels (fustes) ${ }^{57}$.

The lixae are more problematic. Both Festus and an entry in the Suda note their unsavory reputation and deny their formal attachment to the Roman army. Vegetius, however, attests their assignment with calones to the galiarii as well as the requirement that like the regular cavalry and infantry they must learn to swim, and epigraphical evidence suggests lixae could be formally attached to specific units. In fact Frontinus' examples of the use of lixae in military operations find parallels in other sources ${ }^{58}$. Thus it seems that the agasones, lixae, and calones merit the status of soldiers/enemies, 
since they belong to definite units, have officers, wear a type of uniform (the calones and lixae in the Late Roman period apparently were distinguished by helmets), and the calones at least normally bore arms openly and the agasones and lixae certainly do in 2.4.6.

We can now proceed to analyze the stratagems under this heading. 4.7.33 has already been shown a violation. Surprisingly, none of the other stratagems are illegal. In 2.1.6 and 2.4.6 the agasones and lixae act as proper soldiers. With the possible exception of 2.4.20 all the other stratagems involve the betrayal of towns through disguised civilians $\left(3.2 .3^{59}, 7-8,10,3.6\right)$ or calones (3.2.9). If captured by the enemy, all these individuals could be executed as spies, but espionage and treachery of this sort are perfectly legitimate parts of the game. 2.4.20 presents the problem of certain use of noncombatants (women, boys, and all others not in service) in hostile operations, but creating an illusion of reenforcements is not entering combat and therefore not illegal. If any of them were captured, however, and a state of levée en masse or their accordance with the requirements for a soldier was not recognized, they would not merit treatment as prisoners of war.

\section{Feigning Surrender/Desertion}

2.5.27: Before the battle of Cannae began, Hannibal ordered 600 Numidian horsemen to desert to the Romans. They voluntarily handed over their swords and shields and were sent to the rear, where as soon as the fighting started they drew short swords which had been concealed in their tunics, and attacked the Romans from behind. 216 B. C.

2.5.28: The Iapydes surrendered some rustics (pagani) to the proconsul Publius Licinius. After these were stationed behind the Roman battleline, they attacked their captors. Date unknown.

3.16.2: Since his Gallic allies were frequently deserting to the Romans and fighting for them against the Carthaginians, Hamilcar arranged for his most loyal Gauls to desert and then to slay their Roman hosts. Thereafter the Romans refused to receive Gallic deserters. Date unknown.

All three stratagems as breaches of surrender terms or the pledged loyalty of deserters to their hosts unquestionably involve violations ${ }^{60}$.

\section{Feigning Illness}

2.11.2: Pompey suspected the Chaucensians of disloyalty and feared that they would not accept a Roman garrison in their town. So he requested that they admit some of his sick troops for convalescence. Pompey arranged for his strongest men to simulate illness and the town was seized. Date unknown.

The illegality of this stratagem appears moot. Greenspan argues simulation of death, wounds, or illness is a war crime falling under the prohibition of killing or wounding treacherously, while Fleck believes simulation of death is not necessarily a perfidious act $^{61}$. We do not know from Frontinus' account that the false invalids killed or wounded anyone and betrayals are legitimate behavior. Pompey's "sick" soldiers are neither false deserters nor prisoners of war who have surrendered. Moreover, it seems a state of war does not yet exist between the Chaucensians and the Romans. Although some commentators might argue that the stratagem is illegal since it plays upon the humanitarian concern for care of the sick, the more obvious violation is Pompey's perpetration of a hostile act without a declaration of war. 
Drugs, Poison, Assassination

2.5.12: The Carthaginians dispatched Maharbal to suppress some African rebels. Since he knew the Africans had a weakness for wine, he mixed a large quantity of wine with mandragora, a drug with the properties of both poison and a soporific. Later he permitted the Africans to win in a light skirmish and that night he abandoned his camp leaving behind the drugged wine and some baggage. The Africans then seized the camp, drank themselves into a stupor, and became an easy prey for Maharbal upon his sudden return. Date unknown.

2.5.30: Lucullus had repeatedly defeated Mithridates in battle, so Mithridates decided to try a different approach. He hired Adathas to desert to the Romans, to win their confidence, and then, when an opportunity was offered, to assassinate Lucullus. Adathas was received by the Romans, but never gained the chance to carry out his mission and returned to Mithridates. 72 B. C.

3.7.6: When the town of Crisa was under siege, Cleisthenes of Sicyon cut off the aquaducts. Later, when the Crisaeans were desperate from thirst, he restored their water supply now tainted with hellebore. Cleisthenes was thus able to capture the town beset by diarrhoea. At some point 595-585 B. C.

4.7.10: Hannibal urged that in naval battles Antiochus III should throw jars filled with vipers onto the enemy ships to disrupt the functioning of their crews. At some point 196-190 B. C.

4.7.11: Prusias of Bithynia used this same stratagem of snakes, when his fleet was about to yield in battle. 184 B. C.

The use of poisonous snakes (4.7.10-11) and Mithridates' attempted assassination of Lucullus (2.5.30) are obvious breaches of law ${ }^{62}$. Although Maharbal's ruse with drugged wine has modern parallels as late as World War I, contamination of food and water intended for enemy consumption falls under the general prohibition of poison ${ }^{63}$. Much the same applies to 3.7.6: to cut off the water supply was permissible, but contamination of the water was not ${ }^{64}$.

\section{Destruction of Cultural Property}

3.2.5: The Athenian Cimon captured a town in Caria without a fight, when he set fire to a sacred temple and grove by night and thus elicited the townspeople to come outside their walls to extinguish the blaze. c. 470 B. C.

This stratagem violates the rule that religious property is immune from destruction unless employed for hostile purposes ${ }^{65}$.

\section{Misuse of Prisoners of War}

1.2.5: To gain intelligence about his opponents in Spain, Marcus Cato ordered a surprise attack on an enemy outpost. One of the prisoners was brought back and under torture told all. $195 \mathrm{~B}$. C.

1.4.1: When Aemilius Paulus led his army along a narrow Lucanian coast road, the Tarentine fleet attacked him at long range with catapults. In response, Aemilius screened his troops from the fire with prisoners and thus halted the attacks. $282 \mathrm{~B}$. C. 1.4.2: Agesilaus, returning from Phrygia and loaded down with booty, suffered harassing attacks on both flanks as he marched. To stop this he placed a file of prisoners on both sides of the army. $396 \mathrm{~B}$. C.

1.5.20: Spartacus found his forces trapped when Marcus Crassus surrounded his position with a ditch. So by night he escaped by filling the ditch with the bodies of prisoners and cattle which he had killed. 71 B. C. 
1.11.17: Since the sight of the Persians inspired terror in Agesilaus' troops, he ordered his Persian prisoners to be stripped and their white soft bodies, contemptuous to Greeks, to be displayed to his men. 395 B. C.

1.11.18: Gelon, the tyrant of Syracuse, likewise displayed naked Carthaginian prisoners to arouse contempt of the foe. $480 \mathrm{~B}$. C.

3.5.1: The Thracians, well supplied in the mountains, hoped that Clearchus the Spartan would be forced by lack of food to abandon his operations. Clearchus, however, when the thought Thracian envoys were on their way to him, executed one of the prisoners and distributed parts of his body among his troops, as if it were food. The Thracians, impressed by Clearchus' determination, surrendered. At some point 402-401 B. C. 3.8.2: The Theban Pelopidas intended to attack simultaneously two towns of the Magnetes not far apart. He arranged in advance that as he approached one of the towns four horsemen with garlands on their heads and flushed with victory would appear, the forest between the cities would be set ablaze, and prisoners dressed in the fashion of the other town would be exhibited. The ruse worked, and the town surrendered in the belief its sister-city was already taken. At some point 369-364 B. C.

3.15.4: When the Germans besieged the Roman survivors of the Teutoburg Forest debacle and believed them short of food, the Romans led their prisoners around their storehouses for an entire night, then cut off their hands, and released them. The exprisoners convinced their comrades that the Romans were well supplied. 9 A. D.

3.16.4: To stop desertion from his army, Hannibal openly stated for the ears of the Roman spies in his camp that Carthaginian deserters were really spies sent to learn the Roman plans. When this was reported, the Romans arrested all deserters, cut off their hands, and sent them back. At some point 218-202 B. C.

All these stratagems involve illegalities. Prisoners of war may not be tortured to obtain information $(1.2 .5)^{66}$, nor executed without trial (3.5.1) even if the prisoners impede the military expediency of their captors, much less if their deaths promote a military purpose $(1.5 .20)^{67}$. Another obvious breach is using prisoners as screens against hostile fire $(1.4 .1-2)$, since prisoners cannot be employed to render a combat zone immune and must be evacuated ${ }^{68}$. The rather well-known morale booster of Agesilaus and Gelon (1.11.17-18) breaks the rule of the humane treatment of prisoners and the demand that they be protected from intimidation, insults, and public curiosity ${ }^{69}$. Likewise, Pelopidas' elaborate ruse (3.8.2) would appear to violate the ban on use of prisoners in their captor's armed forces, even if it is voluntary service ${ }^{70}$. Finally, 3.15.4 and 3.16.4 both relate the mutilation of prisoners as punishment - without doubt a war crime ${ }^{71}$ but we should note that these two acts fall within the narrative of the anecdotes without being part of the stratagem per se.

\section{Other War Crimes}

2.9.2: Claudius Nero, after his victory over the Carthaginians at the Metaurus, in which Hasdrubal, Hannibal's brother, was killed, threw Hasdrubal's head into Hannibal's camp as a sign that he could no longer expect reenforcements. $207 \mathrm{~B}$. C.

2.9.3: During the siege of Praeneste Sulla fastened the heads of Praenestine generals on spears and displayed them to the besieged to break their morale. $82 \mathrm{~B}$. C.

2.9.4: The German Arminius also fixed the heads of the slain on spears to exhibit near his opponent's fortifications. $9 \mathrm{~A}$. D.

2.9.5: Domitius Corbulo at the siege of Tigranocerta executed an Armenian noble and with a catapult shot his head into the enemy fortification, where it landed in the middle of a council meeting and caused such dread that the Armenians surrendered. 60 A. D. 
2.10.2: Titus Marcius planned to attack by night two Carthaginian camps not far from each other. The first attack succeeded and he left no one alive to report the incident. The second camp was also taken by surprise. $212 \mathrm{~B}$. C.

4.7.22: The magistrates of Henna in Sicily demanded that Gaius Pinarius, the commander of the Roman garrison, hand over to them the keys to the gates. Pinarius suspected that the city planned to switch to the Carthaginian side and requested a night to consider their demand. In the meantime he announced the treachery of the Greeks to his troops and at dawn he told the magistrates he would give them the keys, if all citizens of the town agreed. When everyone had gathered in the theater and unanimously called for the keys, Pinarius signaled his troops who then massacred the whole populace. 214 B. C.

4.7.23: This anecdote has been recounted above under misuse of the enemy's uniform, insignia, and flag.

Once again, all the anecdotes involve illegalities, although the crimes perpetrated in 4.7.22 (massacre of civilians) and 4.7.23 (sack of a town) are results and not integral parts of the trickery of a stratagem ${ }^{72}$. Indeed the ruse of 4.7 .23 has already been seen to be permissible. In contrast, the clever act of 2.10 .2 is the violation itself: not granting quarter in one camp permitted Marcius' surprise of the second camp ${ }^{73}$. The remaining anecdotes, 2.9.2-5, relating exposure of the decapitated heads of enemy soldiers and generals as a psychological ploy to break an opponent's morale, certainly constitute mutilation of the dead ${ }^{74}$.

IV

This paper has posed the question of the continuity of ancient and modern practice in the conduct of war. As a test case, the use of stratagems in antiquity, as collected by Frontinus, has been analyzed by the criterion of the modern laws of war, as presented in a national military field manual currently in use. Only fifty-nine of Frontinus' 484 stratagems or $12.2 \%$ aroused suspicion of illegality. Analysis of these fifty-nine has yielded the following results: seventeen proved to be permissible ruses ${ }^{75}$ and six anecdotes contained violations which were not integral components of the stratagems ${ }^{76}$. Thus Frontinus' Strategemata includes only forty-three anecdotes or $8.9 \%$ involving breaches of the modern laws of war and only thirty-seven illegal stratagems or $7.6 \% 77$. From the opposite point of view it can be asserted that $91.1 \%$ of the military actions in Frontinus are legitimate today. Therefore, Fleck's statement ${ }^{78}$, that ancient stratagems ignored legal and ethical considerations, and its implication of a wide gap between ancient and modern rules of war rest upon a totally false impression of the ancient conduct of war and the extent to which modern rules exhibit change.

To say the least, the proponents of the school of continuity between ancient and modern warfare will no doubt feel a smug confirmation of their subjective interpretations, although this study represents an isolated attempt to prove continuity objectively. In contrast, those of the school of change may be greatly surprised, if not shocked, to find so little "progress" demonstrable. It cannot be argued, however, that the evidence has been stacked one way or another. Frontinus wrote at the end of the first century and collected anecdotes of events whose dates range from the sixth century B. C. to his own time. He intended to instruct by those examples most illustrative of particular incidents drawn from history and to present solutions for similar situations which could happen again (Strat. 1 praef. 1). There can be no doubt that the Strategemata represents a fair sample of the available evidence. 
that we have by-passed key factors, such as modern warfare's greater destructive power and the immense difference in the scale of operations and the number of people involved. Differences in levels of destructive power and numbers cannot be denied. But even so, this study demonstrates that the basic rules of the game have changed little in 2000 years. Certainly some alterations of the rules have occurred: pillaging, sacking captured towns, wanton destruction, enslavement of defeated populations, mutilation and torture of prisoners, and use of weapons causing unnecessary suffering, to list only a few, no longer can legitimately occur.

It should be realized, however, that the thrust of changes in the laws of war has chiefly emphasized humanitarian concerns and reduction of war's ferocity. With few exceptions written rules limiting the means of violence and controlling maneuvers to put that violence in use, i. e., rules governing operations by the armed forces of one party in conflict with the armed forces of another party, have not changed. Again, this study illustrates the point: only fifty-nine of Frontinus' 484 stratagems even aroused suspicion of violation, thus leaving 425 or $87.5 \%$ as unquestionably legitimate acts of war. In contrast, forty-three of those fifty-nine or $73 \%$ were judged illegal by modern standards. Examination of those forty-three will show them chiefly to involve humanitarian considerations. The continuity of rules governing intensity and especially trickery is confirmed by Frontinus' $91.1 \%$ rate of modern legitimacy.

At no point in the history of Western warfare and Western international law has the employment of stratagems been illegal. Bad faith and treachery in agreements were condemned in antiquity, just as they are today ${ }^{79}$. But even Frontinus did not view all stratagems permissible: he considered assassination and certain cases of betrayal war crimes $^{80}$. The real differences between ancient and modern rules of warfare (apart from the modern emphasis on humanitarian considerations) lie in written rather than unwritten international law and perhaps also in the greater effectiveness of modern public opinion in compelling compliance, for observance and enforcement of international law depend upon the voluntary will and attitude of the parties involved. The Iranian hostage crisis of 1980-81 demonstrated quite strikingly the impotence of enforcement of international law. International tribunals to enforce laws of war and to punish war crimes cannot be counted on in the future, since the trials of Nuremburg and Tokyo after World War II represent unique events spurred on by an intense unity of world opinion, and the Geneva Conventions of 1949 stipulate only the use of national tribunals for judging war crimes ${ }^{81}$. The expediency of the unwritten warrior code and the levels of expectation between two parties in conflict remain the most essential controls on the degree of intensity and trickery in warfare. New stricter definitions of ruse and perfidy ${ }^{82}$, although meritorious in theory, will probably be ignored and unenforceable in practice.

Technology aside, if $91.1 \%$ of Frontinus' stratagems relate permissible military behavior by modern standards, the continuity of rules between antiquity and today for the conduct of war cannot be seriously questioned. Moreover, the rejection of the study of ancient military history by military writers of the nineteenth century, such as Clausewitz and Hamley ${ }^{83}$, and the attitude in some circles that ancient studies can no longer be relevant seem too extreme. The lessons of history cannot be limited to a post- $\mathrm{Na-}$ poleonic or even a post-World-War II perspective, and students of ancient warfare should not feel themselves cut off in a discipline strictly academic and of no immediate consequence ${ }^{84}$. The contemporary ancient military historian need not follow Polybius' dictum (12.25g.1) of being a general and politician before attempting the historian's craft, but pragmatike bistoria is still possible - nothing inherent in the sources forbids it - if practitioners will open their eyes to its possibilities ${ }^{85}$. 
Vorbemerkung: Die hochgestellten Ziffern bei den Titeln bedeuten 1.,2.,3. usw. Auflage.

DarSag = Ch. Daremberg/E. Saglio: Dictionnaire des antiquités grecques et romaines. Paris $1877-1919$

$\mathrm{FM} \quad=$ Field Manual

FVS $\quad=$ H. Diels/W. Kranz: Fragmente der Vorsokratiker

GRBS = Greek, Roman and Byzantine Studies

JHS = Journal of Hellenic Studies

Kl. Pauly = Kleiner Pauly

PIR = Prosographia Imperii Romani

RE = Real-Encyclopädie der klassischen Altertumswissenschaften

REG = Revue des études grecques

RIDA = Revue internationale des droits de l'antiquité

SAWW = Sitzungsberichte der Akademie der Wissenschaften in Wien

VDI = Vestnik Drevnej Istorii

ZRG = Zeitschrift der Savigny-Stiftung für Rechtsgeschichte (Romanistische Abt.)

$\mathrm{ZPE} \quad=$ Zeitschrift für Papyrologie und Epigraphik

1 The following works are the most used: Edward M. Earle, ed., Makers of Modern Strategy (Princeton 1941); Dieter Fleck, Ruses and Prohibition of Perfidy, in Revue du droit penal militaire et de droit de la guerre 13 (1974) 269-314; Morris Greespan, The Modern Law of Land Warfare (Berkeley 1959); John Keegan, The Face of Battle (New York 1976); W. Kendrick Pritchett, The Greek State at War. 4 vols. (Berkeley 1971-85); United States Department of the Army (cit. USLLW), The Law of Land Warfare (FM 27-10: Washington 1956; rev. 1976. - Abbreviations of journals follow the system of L'Année Pbilologique.)

2 Martin van Creveld, Command in War (Cambridge, Mass. 1985) 252.

3 E. g., Renaissance: Earle (n. 1 supra); French Revolution: Jehuda L. Wallach, Kriegstheorien: Ibre Entwicklung im 19. und 20. Jabrbundert (Frankfurt a. M. 1972); Cf. Arther Ferrill, The Origins of War (London 1985) 7, 9-10, 215, 223: no significant change in the art of war occurred between Alexander the Great and Napoleon; real changes are all post-Napoleonic.

4 Carl von Clausewitz, On War, trans. Michael Howard/Peter Paret (Princeton 1976) 173-74; Sir Edward B. Hamley, The Operations of War (London 1889) 5. Clausewitz reacted in part to the tremendous influence of Classical writers on military thought before the French Revolution and especially to citations of ancient examples as literary embellishment. On Hamley see Jay Luvaas, The Education of an Army: British Military Thought, 1815-1940 (London 1965) 130-68 and esp. 135 on Hamley's attitude toward ancient history. Nevertheless, the first major work of modern military theory to omit (and thereby to reject) the Classical tradition antedates Clausewitz by a century; Antoine Marquis de Feuquières, Mémoires sur la guerre. 4 vols (Paris 1731). Cf. Max Jähns, Geschichte der Kriegswissenschaften vomebmlich in Deutschland (München 1891), II, 1467-73.

5 Gaston Bouthoul, Traité de polémologie: sociologie des guerres (Paris 1970)12; Virgilio Ilari, Guerre e diritto nel mondo antica, Parte Prima (Università de Roma, Pubblicazioni dell' Istituto di Diritto Romano e dei Diritti dell' Oriente Mediterraneo 56: Milan 1980) 3-33.

6 Michael Walzer, Just and Unjust Wars (New York 1977) 160; Keegan (n. 1 supra) 296, cf. 325-26, however, where he argues modern battle has abolished itself and become an archaism; van Creveld (n. 2 supra) 9, 52.

7 Walter E. Kaegi, The Crisis in Military Historiography, Armed Forces and Society 7 (1981) 299-316.

8 Basil Henry Liddell Hart, Strategy ${ }^{2}$ (London 1967).

9 Cf. Keegan (n. 1 supra) 27- 29: military history consists of the study of generals and generalship, weapons and weapons systems, institutions and doctrines, and battle.

10 See John Keegan, On Principles of War, Military Review 41 (1961) 61-72; John I. Alger, The Quest for Victory: the History of the Principles of War (Contributions in Military History 30: Westport: Conn. 1982).

11 See Geoffrey Best, Humanity in Warfare (London/New York 1980) and on the Hague Conferences: Jost Dülffer, Regeln gegen den Krieg? Die Haager Friedenskonferenzen von 1899 und 1907 in der internationalen Politik (Frankfurt a. M. 1978).

12 American soldiers are instructed to conduct hostilities with chivalry: USLLW (n. 1 supra), $3=1.1$ par. 3. At a conference of the International Red Cross in 1968 a French general proposed establishment of a new code of chivalry: see Krüger-Sprengel, Kriegslist und Perfidieverbot: völkerrechtliche Regeln für das Verhalten zwischen Kombattanten, Neue Zeitschrift für Webrrecht (1971) 161 ก. 3 .

13 See James A. Aho, Religious Mythology and the Art of War (Contributions to the Study of Religion 3: Westport, Conn. 1981) and Hans Speier, Treachery in War, Social Research 7 (1941) 258-79.

14 Cf. the recent study of Jörg Fisch, Die europäische Expansion und das Völkerrecht: Die Auseinandersetzungen um den Status der überseeischen Gebiete vom 15. Jabrbundert bis zur Gegenwart (Beiträge zur Kolonial- und Überseegeschichte 26: Stuttgart 1984).

15 Unfortunately, the recent semi-popular work of Ferrill (n. 3 supra) revives many of the traits which have tainted the image of military history in scholarly circles. The work suffers inter alia not because 
it treats operational history and the military art rather than the currently fashionable social and economic aspects, but because the author employs numerous arbitrary and subjective value judgements in comparisons from different chronological periods: e. g., no medieval army could have defeated Alexander the Great. His laudatory and uncritical assessment of Alexander is climaxed by discussion of how Alexander could not possibly have made the same mistakes as Napoleon at Waterloo and how Alexander's army, despite the differences in technology, would have defeated Wellington. This is science fiction and a war gamer's fantasy - not history. Ibid., 7-10, 215-23 and my review in Armed Forces and Society 14 (1987) 156-58.

16 See Rudolf Schneider, Legion und Phalanx (Berlin 1913), esp. 100-35; Keegan (n. 1 supra) 64, 69; Clausewitz (n. 4 supra).

17 Ardant du Picq, Battle Studies: Ancient and Modern Battle, trans. John N. Greeley/Robert C. Cotton (Harrisburg 1947); Alfred von Schlieffen, Cannae (Berlin 1925). For du Picq see Stefen Possony/Etienne Mantoux, Du Picq and Foch: the French School, in: Earle (n. 1 supra) 206-33; Wallach (n. 3 supra) 139-48; Keegan (n. 1 supra) 70-71; on Schlieffen see Hajo Holborn, Moltke and Schlieffen: the Prussian-German School, in Earle (n. 1 supra) 172-205; Wallach (n. 3 supra) 89-135.

18 Hans Delbrück, Geschichte der Kriegskunst im Rabmen der politischen Geschichte, 4 vols. (Berlin 1900-20), now in English translation by Walter J. Renfroe, Jr. as History of the Art of War within the Framework of Political History, 4 vols. (Westport: Conn. 1975-85); Johannes Kromayer/Georg Veith, Antike Schlachtfelder, 3 vols. (Berlin 1903-31) and Scblacbten-Atlas zur antiken Kriegsgeschichte (Leipzig 1922-29).

19 Arden Bucholz, Hans Delbrück and the German Military Establishment (Iowa City 1985) 31, cf. Keegan (n. 1 supra) 33-34.

20 Bucholz (n. 19 supra) 21; Keegan (n. 1 supra) 33.

21 Summaries of the debate from opposing viewpoints in Pritchett (n. 1 supra) III, 1-2 and Gordon Craig, Delbrück: the Military Historian, in Earle (n. 1 supra) 263-72. Cf. N. Whatley, On the Possibility of Reconstructing Marathon and Other Ancient Battles, JHS 84 (1964) 119-39: basically a critique of Sachkritik which is taken as a vade mecum in some circles.

22 Donald W. Engels, Alexander the Great and the Logistics of the Macedonian Army (Berkeley 1978). In contrast to the negative attitude toward Delbrück still found among some ancient historians, a recent study of the effects of Spartan invasions of Attica during the Peloponnesian War supports many of Delbrück's views: Victor D. Hanson, Warfare and Agriculture in Classical Greece (Biblioteca di Studi Antichi 40: Pisa 1983) 21 n. 1, 23 n. 4, 52 n. 46, 58 n. 62.

23 The only conceptual study for antiquity remains Friedrich Lammert, "Strategemata«, $R E$, Reihe 2, 4 (1931) 174-81 cf. his »Polyainos 8«, RE 21 (1952) 1432-36. Pritchett (n. 1 supra) III, 330, suggests the need to study the concept of apate (deceit) in Greek society to explain restraints on ruses and deceptions when military advantages could have been gained, while Kaegi (n. 7 supra) 311, deplores the poverty of military historiography in general on the topics of ruse and surprise and their effectiveness. Escaping Kaegi's notice is Barton Whaley, Stratagem: Deception and Surprise in War (Cambridge, Mass. 1969), who attempts a general discussion, although chiefly limiting the definition of stratagem to strategic surprise and offering a detailed analysis only of the period 1914-68. His second book, with J. Bowyer Bell published under the pseudonym J. Barton Bowyer, Cheating (New York 1982), presents a very superficial survey of stratagem in the West as well as a general theory of deception. An attempt to rectify the situation for the Roman Republic, Giovanni Brizzi, $I$ sistemi informativi dei Romani: principi e realtà nell' eta della conquiste oltremare (218-168 a. C.) (Historia Einzelschrift 39: Wiesbaden 1982), suffers from many misconceptions about stratagems and Roman attitudes toward them, which I intend to deal with elsewhere. Among the positive contributions to the study of ancient stratagems we should note Pritchett's ( $n$. 1 supra) chapters on surprise attacks and ambushes, II, 158-89; André Arnaud, Quelques aspects de la ruse et la guerre dans le monde grec du VIII e au Ve siècle (3rd cycle thesis: Paris 1971); and Mirko Grmek, Les ruses de guerre biologiques dans l'antiquité, REG 92 (1979) 141-63. On the language of stratagem see my Stratagem and the Vocabulary of Military Trickery (Mnemosyne Supplement: Leiden 1988).

24 No general history of the laws of war exists, although Best (n. 11 supra) and René Bourdoncle, De l'influence des ruses sur l'évolution du droit de la guerre (Annales de l'Université de Lyon, Sér. 3, Droit, fasc. 17: Paris 1958) 29-133, attempt to fill the gap for the nineteenth and twentieth centuries in some respects. The works of Whaley (n. 23 supra) practically ignore all legal questions. For antiquity Ilari's Guerre e diritto (n. 5 supra) purports to be a comprehensive treatment of Greek laws of war through the third century B. C., but his identification of the laws of war almost exclusively with the right of the victor leads to an emphasis on treatment of the conquered and limits on violence rather than to the operational ethics of stratagems. Peter Karavites, Capitulations and Greek Interstate Relations (Hypomnemata 71: Göttingen 1982) examines the laws of war on the surrender and destruction of Greek cities and offers a good survey of the development of the Greek aristocratic warrior code, although there is room to disagree with some of his conclusions. On the Roman side Antonio Carcaterra, Dolus Bonus/Dolus Malus: Esegesi di D. 4.3.1.2-3 (Naples 1970), argues the existence of dolus bonus, a Roman euphemism for stratagem, as a principle of Roman private law - with dubious results in the view of Andreas Wacke, ZRG 88 (1971) 440-45, 94 (1977) 184-246, 
and RIDA 27 (1980) 349-86 - but fails to treat the implication of dolus bonus for Roman Republican foreign policy and laws of war. Nor does Ilari's massive bibliography on Roman just war contribute to legal aspects of stratagems: L'interpretazione storica del diritto di guerre Romano fra tradizione romanistica e guisnaturalismo (Università di Roma, Pubblicazioni dell' Istituto di Diritto Romano e dei Diritti deli' Oriente Mediterraneo 57: Milan 1981).

25 See Maurice R. Davie, The Evolution of War (New Haven 1929) esp. 176-81; Harry Holbert Turney-High, Primitive Warfare, its Practice and Concepts ${ }^{2}$ (Columbia 1971) 112-37.

26 On the origins of military theory see my: The Origins of Military Theory in Ancient Greece and China, International Commission of Military History, Acta 5, Bucarest 1980 (Bucarest 1981) 74-79.

27 Clemens Bosch, Die Quellen des Valerius Maximus (Stuttgart 1929) esp. 8-13; Val. Max. 7.4 cf. 7.3, 9.6 praef.; Aen. Tact. 11.2, 28.4-29.12; Plb. 1.57.5.

28 On the life and writings of Frontinus see Alfred Kappelmacher, Iulius 243, $R E 10$ (1918) 591-606; $P I R^{2}$ IV, I 322; Gerhard Bendz, Frontin, Kriegslisten (Schriften und Quellen der alten Welt 10: Berlin 1963) 1-4; Werner Eck, Senatoren von Vespasian bis Hadrian (Vestigia 13: Munich 1970) 77-81, 131, 133 and Iulius 243, RE, Suppl. 14 (1974) 208-209; V. V. Kuchma, Some Disputed Questions concerning the Strategemata of Frontinus, VDI (no. 4, 1984) 45-55 (in Russian).

29 The De officio legati has been ignored by all writers on Frontinus and is cited only in John Lydus, Mag. 1.47. On the genre see Fritz Schulz, Geschichte der römischen Rechtswissenschaft (Weimar 1961) 309-15.

30 Xen., Mem. 3.5.22; Phil. Mech., Mech. Syn. 5.D.97 Garlon; Plb. 1.27.6, 57.5; 3.18.9, 78.1; 5.47.4, $70.7 ; 8.7 .6 ; 11.22$.1. I intend to treat the history of the word strategema and the Graeco-Roman vocabulary of military trickery in detail elsewhere.

31 Front., Strat. 1 praef. 1,4 cf. 4 praef.

32 On Polyaenus see the articles by Lammert (n. 23 supra); Friedal Schindler, Die Überlieferung der Strategemata des Polyainos, SAWW 284 (1973), Abh. 1; Alphonse Dain, Les stratégists byzantins, Travaux et mémoires II (1967) 333-35. There is some reason to doubt Polyaenus' claim to Macedonian origin as well as identification of the author of the Strategika with the Macedonian Polyaenus who wrote a Tactica and who appears in the Suda. This problem must be pursued elsewhere.

33 Bibliography in Bendz (n. 28 supra) 14. Bendz has successfully defended the authenticity of the fourth book in Die Echtheitsfrage des vierten Buches der frontinischen Strategemata (Lunds universitets årsskrift, N. F. Avd. 1, Bd 34, nr. 4: Lund 1938).

34 E. g., Waldemar Erfurth, Surprise, trans. Stefen T. Possony/Daniel Vilfroy (Harrisburg 1943) 1; Whaley, Stratagem (n. 23 supra) 3 n. 1, 89 and Cheating (n. 23 supra) 23-24; Fleck (n. 1 supra) 273. On the other hand, Eugen Weyde, Die Trojanische List: zur Theorie und Praxis der unkonventionellen Kriegsfübrung (Cologne 1965) 15, 18, and Krüger-Sprengel (n. 12 supra) 165 n. 13, know Polyaenus but not Frontinus.

35 Fleck (n. 1 supra) 273, citing Front., Strat. 4.4.2, 1.4.1 and Polyaenus 1.45.3. It is interesting to note that the purpose of Fleck's article is to suggest improvements to the proposed Additional Protocols to the Geneva Conventions of 1949, formulated 1969-77, which contain new definitions of ruse and perfidy. On the new Protocols see Jan H. W. Verzijl, International Law in Historical Perspective, IX-A: the Laws of War (Alphen aan den Rijn 1978) 359; Fleck (n. 1 supra) 285-98; Thomas J. Murphy, Sanctions and Enforcement of the Humanitarian Law of the Four Geneva Conventions of 1949 and Geneva Protocol of 1977, Military Law Review (1984) 3-77; Antonio Cassese, ed., The New Humanitarian Law of Armed Conflict, 2 vols. (Naples 1979); and Michael Bothe/Karl Josef Partsch/Waldemar Solf, New Rules for Victims of Armed Conflict (The Hague 1982).

36 See n. 1 supra.

37 The decision to use a national manual as a standard of international law can be in itself controversial. At the Nuremburg trials national military manuals were rejected as evidence of customary international law and the United Nations later affirmed the principles of international law recognized at Nuremburg. On the other hand, the number of separate and dissenting opinions at the Tokyo trials undercut confidence in that decision. Furthermore, international law has no system of precedent, as in Anglo-Saxon systems of law, and the decision in one case has no binding force in another. Thus it seems preferable to view national field manuals, articles of war, etc. as operative laws of war and the principles of international tribunals as theoretical, since national manuals provide the rules and guidelines actually in force and include as much of the law of international organizations as each sovereign state recognizes. On the problem see Richard I. Miller, ed., The Law of War (Lexington, Mass. 1975) 11-12; Greenspan (n. 1 supra) 7; Peter Karsten, Law, Soldiers, and Combat (Contributions in Legal Studies 3: Westport. Conn. 1978) 25; Igor P. Blishchenko, Judicial Decisions as a Source of International Humanitarian Law, in Cassese (n. 35 supra) I, 43-44.

38 No violations were found in Strat. 4.1-6, so omission of these ninety-nine anecdotes does not greatly affect the results except for increasing the percentage of violations, i. e., division of the number of violations by 484 rather than 583 .

39 USLLW (n. 1 supra) $17=2.2$ par. 29, 22-23 = 2.5 par. 48-51. Par. 51 includes a list of permissible stratagems. Cf. Lassa F. L. Oppenheim, International Law, ed. Hersh Lauterpacht, $\mathrm{II}^{7}$ (London 1952) 428-29 and Greenspan 319-20 for other lists.

40 USLLW (n. 1 supra) $23=2.5$ par. 52-55. For commentary see Fleck (n. 1 supra) 277-92, where the pertinent literature is cited. 
41 USLLW (n. 1 supra) 17-18 = 2.2 par. 31, 2.3 par. 37.

42 Ibid. $180=8.2$ par. 504 . Rules concerning prisoners of war and various other violations found in Frontinus' anecdotes have been omitted from this discussion for brevity's sake, but will be presented when pertinent in the following section.

43 Ibid. $168=7.3$ par. 465 (in context of a truce).

44 On sophistic interpretations in antiquity see my: Sophistic Interpretations and Greek Treaties, GRBS 25 (1984) 253-74.

45 Greenspan (n. 1 supra) 321; Fleck (n. 1 supra) 293-94; Oppenheim (n. 39 supra) II', 509; Gerhard von Glahn, Law among Nations: an Introduction to Public International Law ${ }^{3}$ (New York 1976) 616; Paul Fauchille, Traité de droit international public (Paris 1921) II ${ }^{8}$, 408-410.

46 National costumes as uniforms: 2.5 .10 (quosdam ex suis babitu Illyriorum instruxit), 2.5 .15 (vestem eius suo militi dederunt), 2.9 .10 (Persae [.. .] et navigia et babitum superstantium adgnoscerent, nibil caverunt), 3.2.4 (instructi eorum qui exspectabantur ornatu admissique per bunc errorem), 3.2 .11 (clamide [...] et galeari ad Macedonicum omatus est babitum); insignia: 3.14 .1 (tamquam Caesarianus tribuni cormicularius), 4.7 .12 (eorumque armis et insignibus inter suos distributis [. . .] quos sociali babitu fefellerat). Vergil's famous line, Dolus an virtus, quis in boste requirat? (Aen. 2.390), is occasioned by Trojans disguising themselves with Achaean equipment and insignia.

47 See Lionel Casson, Ships and Seamanship in the Ancient World (Princeton 1971) 246-47 with nn. 87-88.

48 Valentine Jobst, Is the Wearing of the Enemy's Uniform a Violation of the Laws of War? American Joumal of Intemational Law 35 (1941) 435-42 cf. USLLW (n. 1 supra) $23=2.5$ par. 52,54 .

49 USLLW (n. 1 supra) $180=8.2$ par. $504 \mathrm{~g}$ : "Use of civilian clothing by troops to conceal their military character during battle."

50 See Best (n. 11 supra) 118-20, 200, 298; Miller (n. 37 supra) 160-65; Verzijl (n. 35 supra) IX-A, 86; Greenspan 59-60; Oppenheim (n. 39 supra) II', 215, 256-57.

51 USLLW (n. 1 supra) $25=3.1$ par. 61 . A. $1-2,31=3.2$ par. $74,34=3.2$ par. $80-81$. In the case of a levée en masse only the final two criteria apply: par. 61. A. 6.

52 Cic., Off. 1.36-37; Plut., Mor. 273 E-F. For the similar Greek view of a legally defined enemy see Democritus, FVS6 68 B 260; Plut., Mor. 273F cf. 236E; Xen., Cyr. 4.1.3.

53 The Roman army's campfollowers have attracted but little scholarly attention: Edmond Saglio/ Masquelez, Calones, DarSag I.2 (1908) 852: Alfred Neumann, Calones, Kl. Pauly I (1964) 1018 and Lixa, III (1969) 699; Walter Sontheimer, Agaso, ibid. I, 115; René Cagnat, Lixa, DarSag III (1904) 1279; Robert Grosse, Lixa, RE 13 (1926) 929-30; and for the epigraphical evidence see Michael P. Speidel, Lixa of the Third Thracian Cohort in Syria: a New Inscription, ZPE 38 (1980) 146-48. The servi of 2.1.6, a Greek anecdote, are probably calones: cf. 3.2.9. As a Latin writer, Frontinus casts both Greek and Roman anecdotes in Roman terms, and thus Roman practice must be the basis upon which we judge the anecdotes, although historically Greek and Roman practices are not always the same. On campfollowers in Greek and Hellenistic armies see Pritchett (n. 1 supra) I, 51 ; Maurice Holleaux, Ceux qui sont dans le bagage, REG 39 (1926) 354-66.

54 USLLW (n. 1 supra) $26=3.1$ par. 61.A.4.

55 Veg. 3.6: ex ipsis calonibus, quos galiarios vocant. I take Vegetius' use of the present tense to indicate a contemporary practice, since it intrudes on his discussion of the calones presented in secondary tense sequence and introduced with antiqui diligentissime praecavebant.

56 Arnold Schober, Die römischen Grabsteine von Noricum und Pannonien (Österreichisches Archäologisches Institut, Sonderschrift 10: Vienna 1923) Abb. 54, 69, 109, 181; Speidel (n. 53 supra) 148 n. 10.

57 Serv. ad Aen. $6.1 \mathrm{cf}$. Saglio/Masquelez and Neumann in n. 53 supra.

58 Festus s. v. lixae, 103 Lindsay; Suda s. v. leixai; Veg. 1.10; Speidel (n. 53 supra) 146, 147 n. 8; for lixae in military operations see Tac., Hist. 3.20.3; 4.20.2, 22.3.

59 It is not clear if Hannibal's men are disguised as Romans in civilian or military dress.

60 USLLW in n. 39 supra.

61 Greenspan (n. 1 supra) 317 cf. USLLW (n. 1 supra) $17=2.2$ par. 31 ; Fleck (n. 1 supra) 283. Also see Josef Malcher/Heinz Dundalski, Taktische Täuschung, Webrkunde 6 (1957) 407; Krüger/Sprengel (n. 12 supra) 169.

62 See $n .41$ supra.

63 See Greenspan (n. 1 supra) 317. Faucille, (n. 45 supra) II ${ }^{8}, 124$, alleges that in World War I the Germans would leave behind poisoned food in trenches and areas they abandoned, but given the date of this work (1921) this may be French propaganda. On the other hand, British preparations for the battle of Gaza (31 December 1917) included dropping by air packages of cigarettes laced with opium on the Turkish front lines. See Whaley/Bell (n. 23 supra) 82.

64 The prohibition of poison and poisoned weapons in the West is as old as Homer (Od. 1.259-63) and has continued as a traditional element of Western military practice with little justification or explanation in publicists and jurists, ancient or modern. I hope to treat the question of poison and stratagems in greater detail elsewhere. 
68 Ibid. $40=3.5$ par. 99 cf. $39=3.4$ par. 95 .

69 Ibid. $36=3.3$ par. 89 .

70 Ibid. $32=2.2$ par. $32,35=3.3$ par. 87 , cf. Greenspan (n. 1 supra) 101, 104.

71 USLLW (n. 1 supra) $36=3.3$ par. $89,63=3.16$ par. $163,64=3.16$ par. 165 .

72 Ibid. $19=2.4$ par. $41,106=5.3$ par. $266,107=5.3$ par. 271 (massacre of civilians), $21=2.4$ par. 47 (pillage), $150=6.5$ par. 397 .

73 Ibid. $17=2.2$ par. $28-29,19=2.4$ par. 41 .

74 Ibid. $85-86=4.2$ par. $216,218,180=8.2$ par. $504 \mathrm{c}$, cf. Greenspan (n. 1 supra) $76-77$.

$751.1 .7,4.6,13 \mathrm{a} ; 2.1 .6,4.6,20,5.15 ; 3.2 .3,7-11,3.6,14.1 ; 4.7 .18,23$.

$76 \quad 3.4 .3-4,6,15.4,16.4 ; 4.7 .23$.

77 The apparent discrepancy, i. e., $17+6=23$ and therefore $59-23=36$ illegal stratagems, is explained by 4.7.23, which contains both a permissible ruse and a violation not part of the ruse.

78 N. 35 supra.

79 E. g., Il. 3.276-91, 4.234-37, 7.351-53; Cic., Off. 1.39, 3.108-109, 111; Val. Max. 9.6.

80 This is clear from Frontinus' use of Roman legal terms. The only two occurrences of facinus (crime) in the Strategemata characterize assassination: $2.5 .30,4.4 .2$. The famous anecdote of the Falerian schoolmaster, who offered to betray his students to Camillus, is termed a fraus (deceit, fraud) : 4.4.1. The only other use of fraus by Frontinus, 4.7.22, characterizes the treachery of the Greeks at Hennae and thereby serves to justify the Romans' massacre of the inhabitants. Frontinus never designates a stratagem as dolus, the most common legal term for trickery or deceit in his own time. The connections between legal vocabulary and the language of stratagem must be pursued elsewhere. Cf. n. 23 supra.

81 See G. I. A. D. Draper, The Ethical and Juridical Status of Constraits in War, Military Law Review 55 (1972) 182-83.

82 See n. 35 supra.

83 See n. 4 supra.

84 Even the modern theory of deterrence has a Classical base: see Wolfgang Haase, Si vis pacem, para bellum. Zur Beurteilung militärischer Stärke in der römischen Kaiserzeit, in Jenö Fitz, ed., Limes: Akten des XI. intemationalen Limeskongresses (Budapest 1977) 721-56. Cf. Edward N. Luttwack, The Grand Strategy of the Roman Empire (Baltimore 1976).

85 I wish to acknowledge that research for this paper was conducted under a fellowship from the Alexander von Humboldt Foundation and that an initial draft was written at the Institute for Advanced Study at Princeton. Preparation of the final draft has come with the generous support of the Harry Frank Guggenheim Foundation. 


\section{Veröffentlichungen des Militärgeschichtlichen Forschungsamtes}

Erscheint im Herbst:

\section{Das Deutsche Reich und der Zweite Weltkrieg}

Bd 5: Organisation und Mobilisierung des deutschen Machtbereichs

Teilband 1: Kriegsverwaltung, Wirtschaft und personelle Ressourcen 1939-1941.

Von Hans Umbreit, Rolf-Dieter Müller, Bernbard R. Kroener

Deutsche Verlags-Anstalt. Stuttgart

Mit zahlreichen Skizzen, Tabellen und Graphiken. Subskriptionspreis 58,- DM (später 78, - DM)

Einleitung (Wilhelm Deist)

Erster Teil: Auf dem Weg zur Kontinentalwirtschaft

(Hans Umbreit)

I. Die Planungen für die Verwaltung besetzter Gebiete vor Ausbruch des Krieges

II. Stadien der territorialen "Neuordnung" in Europa

III. Die vorgezogene „Neuordnung“: de jure und de facto annektierte Gebiete

IV. Verwaltung und Sicherung des deutschen Machtbereichs

V. Die Ausbeutung der besetzten Gebiete

VI. Herrschaftsanspruch und Herrschaftswirklichkeit in den besetzten Gebieten

VII. Kollaboration und Widerstand

Zweiter Teil: Die Mobilisierung der deutschen Wirtschaft für Hitlers Kriegführung (Rolf-Dieter Müller)

I. Die Vorbereitung auf den totalen Krieg

II. Improvisation statt Planung: Die „Übergangswirtschaft“

III. Aushilfslösungen im Frühjahr 1940

IV. Die Hybris des Siegers: Der Verlust des Rüstungsvorsprungs nach dem Ende des FrankreichFeldzuges

V. Die Lähmung der Rüstung

VI. Der Weg in die Krise

VII. Anfänge einer Reorganisation der Kriegswirtschaft am Jahreswechsel 1941/42

Dritter Teil: Die personellen Ressourcen des Dritten Reiches im Spannungsfeld zwischen Wehrmacht, Bürokratie und Kriegswirtschaft 1939-1942

(Bermbard R. Kroener)

Einleitung: Blitzkriegsstrategie und Blitzkriegswirtschaft. Zur Genesis eines Begriffes

I. Organisation und Durchführung der militärischen Mobilmachung

II. Die Personallage der Wehrmacht bei Kriegsausbruch

III. „Menschenbewirtschaftung" - Bevölkerungsverteilung im Spannungsfeld zwischen Wehrmacht und Kriegswirtschaft (September 1939- Juni 1941)

IV. Die Entwicklung der militärischen Personalsteuerung bis zum Sommer 1941

V. Die Winterkrise 1941/42. Die Verteilung des Mangels oder Schritte zu einer rationelleren Personalbewirtschaftung

VI. Blitzkrieg oder totaler Krieg? Ideologische oder politisch-militärische Implikationen als Reaktion auf das Trauma des Ersten Weltkrieges

Bilanz (Umbreit, Müller, Kroener) 